\title{
Prevalent fatty acids in cashew nuts obtained from conventional and organic cultivation in different stages of processing
}

Denise Josino SOARES ${ }^{1 *}$, Pedro Hermano Menezes de VASCONCELOS ${ }^{2}$, André Luiz Melo CAMELO², Elisane LONGHINOTTI ${ }^{2}$, Paulo Henrique Machado de SOUSA ${ }^{3}$, Raimundo Wilane de FIGUEIREDO ${ }^{1}$

\begin{abstract}
Brazil is one of the three largest producers of fruits in the world, and among those fruit trees, the cashew tree stands out due to the high nutritional and commercial value of its products. During its fruit processing, there are losses in some compounds and few studies address this issue. Over the last decade the conventional system of food production has been substituted for the organic cultivation system, which is a promising alternative source of income given the global demand for healthy food. Therefore, this research aimed to characterize and quantify the prevalent fatty acids found in cashew nuts obtained from conventional and organic cultivation during various stages of processing. The prevalent fatty acids found were palmitic, linoleic, oleic, and stearic acid. The average of these fatty acids were $6.93 \pm 0.55 ; 16.99 \pm 0.61 ; 67.62 \pm 1.00$ and $8.42 \pm 0.55 \mathrm{~g} / 100 \mathrm{~g}$, respectively. There was no reduction in the palmitic, oleic and stearic fatty acid contents during processing. Very little difference was observed between the nuts obtained from conventional and organic cultivation, indicating that the method of cultivation used has little or no influence on the content of cashew nut fatty acids.
\end{abstract}

Keywords: essential fatty acids; organic food; food processing.

\section{Introduction}

Cashew nut is composed of a shell, film and the nut itself. The nut is the most important product (LIMA; DUARTE, 2006).

The essential linoleic fatty acid cannot be produced by the human body (SUÁREZ-MAHECHA et al., 2002), and therefore it has to be obtained from foods. The essential fatty acids are necessary for the proper functioning of the body and play an important role in the regulation of several metabolic, transport, and excretion processes (TINOCO et al., 2007).

Nuts are a good source of unsaturated fatty acids, including monounsaturated (MUFA) and polyunsaturated fatty acids (PUFA) (MAGUIRE et al., 2004). The oleic acid belongs to the MUFA group and plays an important role in reducing LDL cholesterol in the body (MEZZOMO et al., 2010). The linoleic acid is extremely important for the development and maintenance of the nervous system and physiological function in humans (FAGUNDES, 2002). Cashew nut has a high nutritional value because it is rich in polyunsaturated fatty acids (PAIVA; GARRUTI; SILVA NETO, 2000) since it contains oleic $(\omega-9)(59-61 \%)$ and linoleic $(\omega-6)(16-20 \%)$ fatty acids (RYAN et al., 2006).

Nuts, in general, are healthy foods, and their consumption is associated with a reduced risk of cardiovascular disease and diabetes (HEINIG, 2006). These benefits are related to the nutritional composition of nuts that are rich in unsaturated fatty acids, fiber, minerals, and proteins (CHEN; LAPSLEY; BLUMBERG, 2006). According to Amico et al. (2006), the fatty acids present in almonds have beneficial properties for health, such as cholesterol reduction and anticarcinogenic activity.

Li et al. (2011), studying the effect of consumption of almonds for 12 months in Chinese patients with type 2 diabetes mellitus, observed that the consumption of these nuts in a healthy diet has benefits including improved glycemic control and lipid profile, which contributes to reduce the risk of cardiovascular disease.

The increasing search for healthier foods has led to the substitution of conventional food production for organic cultivation (CHITARRA; CHITARRA, 2005). Conventional cultivation depends on chemical inputs such as fertilizers and pesticides, whereas organic cultivation excludes the use of these substances (GLOVER; REGANOLD; ANDREWS, 2000).

Chemical agricultural farming (conventional cultivation) can harm producers and consumers' health and cause environmental damage. According to Agrorgânica (2013), the use of organic products helps reduce the number of one million producers worldwide who have their health damaged each year through contact with pesticides. Researchers of the Instituto Biodinâmico (INSTITUTO..., 2013) found that the products used in conventional agriculture have higher nitrogen content than those produced in the organic system. This can have adverse consequences for people's health due to the carcinogenic potential of nitrogen compounds.

\footnotetext{
Received $1 / 8 / 2012$

Accepted 29/1/2013 (005809)

Departamento de Tecnologia de Alimentos, Universidade Federal do Ceará - UFC, Av. Mister Hull, 2977, CEP 60021-970, Fortaleza, CE, Brazil, e-mail: denisejosino@hotmail.com

${ }^{2}$ Departamento de Química Orgânica e Inorgânica, Universidade Federal do Ceará - UFC, Av. Mister Hull, 2977, CEP 60021-970, Fortaleza, CE, Brazil

${ }^{3}$ Instituto de Cultura e Artes, Universidade Federal do Ceará - UFC, Av. Mister Hull, 2977, CEP 60021-970, Fortaleza, CE, Brazil

${ }^{*}$ Corresponding author
} 
There are very few works in the literature comparing foods produced by conventional and organic cultivation. CrecenteCampo et al. (2012), who compared strawberries cultivated by conventional and by organic methods, found that organic strawberries have significantly higher levels of anthocyanins and ascorbic acid than those of conventional fruits. Lombardo, Pandino and Mauromicale (2012) found that potatoes produced by organic farming have a higher nutritional value due to their higher total phenolic and lower nitrate content and better sensory performance after they have been fried than potatoes produced by conventional farming. Despite the fact that some studies have revealed differences between these two forms of cultivation, little is known as to whether there is any variation in cashew nuts obtained from organic cultivation system when compared to the conventional system.

During its fruit processing, there are losses in some compounds and few studies address this issue. Therefore, is important to study the nutritional value of different types of food in order to know the influence of processing and preservation technology on their chemical composition (TUDELA; ESPÍN; GIL, 2002; ZHANG; HAMAUZU, 2004).

The main losses from cashew nut processing occur due to the high temperatures applied, which cause moisture decrease (SOARES et al., 2012a). Other changes that can occur during cashew nut processing are: oxidative process, since this nut has high lipids content (SILVA; ASCHERI; SOUZA, 2010) and reduction in phenolic compounds, since most of the phenolic compounds can be found in the film, and less than $10 \%$ of these compounds are retained in the nut when the film is removed (BLOMHOFFI et al., 2006).

Neither peeling nor storing the cashew nut in flexible packaging covered with laminated film for 180 days caused any reduction in its lipid content, as observed by Soares et al. (2012a, b), respectively. The literature on this subject contains no studies detailing the changes in the fatty acid profile of cashew nuts during these processing steps.

Given the aforementioned, this research aimed to characterize and quantify the prevalent fatty acids present in cashew nuts obtained from conventional and organic cultivation during various stages of processing.

\section{Materials and methods}

The study was performed with cashew nuts donated by a large company in the Northeast region, located in the city of Mossoro in the state of Rio Grande do Norte. Both the conventional and organic cashew nuts were cultivated under the same environmental conditions and the trees (early dwarf cashew tree) were from the same specie (Anacardium occidentale).

Conventional and organic nuts were collected at four stages of processing: after shelling, before peeling, after peeling, and during packaging (Figure 1).

The nuts were placed in plastic bags and then crushed using a domestic blender at the time of analysis.
Lipid extraction was performed according to the Bligh and Dyer (1959) modified by Instituto Adolfo Lutz (INSTITUTO..., 2008). Fifty grams of the homogenized sample was weighed in a beaker to which $50 \mathrm{~mL}$ of chloroform and $100 \mathrm{~mL}$ of methanol were added. Subsequently, $50 \mathrm{~mL}$ of chloroform and $50 \mathrm{~mL}$

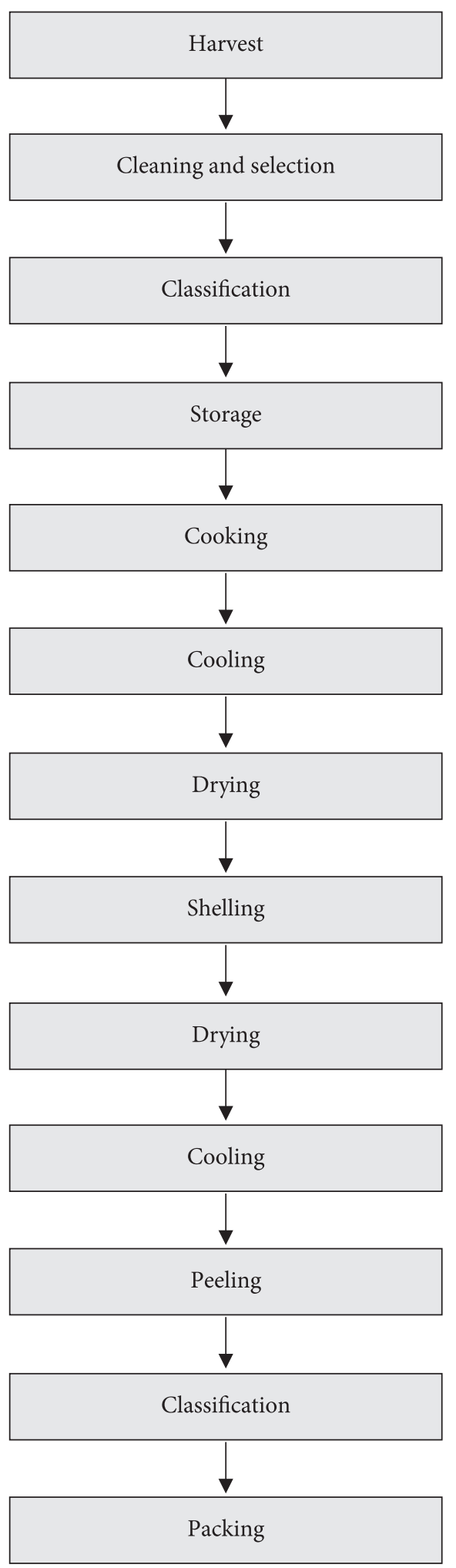

Figure 1. Stages of the processing of cashew nuts. 
water were added. This mixture was stirred for 15 minutes using a magnetic stirrer. The material was filtered using a glass funnel with a filter paper containing anhydrous sodium sulphate into a separating funnel of $500 \mathrm{~mL}$. After complete separation and clarification, the chloroform layer was collected in a flatbottomed flask and then evaporated on a rotating evaporator until complete removal of the solvent.

The preparation of methyl esters was performed with the mixture of $100 \mathrm{mg}$ of lipids extracted, $2 \mathrm{~mL}$ of $\mathrm{n}$-hexane (chromatography grade), and $0.2 \mathrm{~mL}$ of hydroxide potassium $2 \mathrm{M}$ solution in methanol (chromatography grade). This solution was stirred at room temperature in a vortex for 30 seconds. Next, $3 \mathrm{~mL}$ of saturated solution of sodium chloride were added. The upper phase was analyzed. The identification and quantification of fatty acids were performed using a Shimadzu GCMS QP2010 gas chromatograph equipped with mass selective detector and a DB-1 column $(30 \mathrm{~m}$ long $\times 0.25 \mathrm{~mm}$ thickness $\times 0.25 \mathrm{~mm}$ internal diameter) using helium carrier gas. The chromatograph was programmed as follows: initial temperature of $25^{\circ} \mathrm{C}$ and an increase of $50^{\circ} \mathrm{C} /$ minute until the temperature of $230^{\circ} \mathrm{C}$. The temperatures of the injector and column were set at $250^{\circ} \mathrm{C}$ and $110^{\circ} \mathrm{C}$, respectively. The injector was operated with a split ratio of 10. A co-injection of the internal standard was performed in all injections. The internal standard used was methyl heptadecanoate at $0.2 \mu \mathrm{g} / \mathrm{mL}$. This compound was purchased from Sigma.

The peaks were identified by comparison with those of authentic fatty acid standards. The percentage of individual fatty acids was calculated from the peaks area using an external five-point calibration curve for each fatty acid studied.

There were three collections between the months of October 2009 and February 2010, and two samples were taken at the time of each collection (one from a conventional source and one from an organic source).

The experiment was conducted as a randomized block design using two cultivation forms (conventional and organic cultivate) in the main plots and four points of collection (four stages of the processing) in the sub plots with three replications. The results were statistically evaluated by interaction and variance analysis. Since the results proved to be significant according to the $\mathrm{F}$ test, the treatments were compared by the Tukey test at 5\% probability using the SAS Statistical Software version 8.1 (STATISTICAL..., 2006).

\section{Results and discussion}

The prevalent fatty acids found in cashew nuts were palmitic, linoleic, oleic and stearic acids (Figure 2). Other fatty acids were also found in cashew nuts, but in trace amounts.

There was significant interaction $(\mathrm{p}<0.05)$ between the stages of the processing and the cultivation methods for the palmitic and stearic fatty acids, which indicates that there were significant differences $(\mathrm{p}<0.05)$ between the two forms of cultivation, either between the storage times alone or between both methods of cultivation and storage time. Because of this significant interaction regarding palmitic and stearic fatty acid contents, the Tukey test was performed, and these interaction data is shown in Table 1.

The average value of palmitic acid was $6.93 \pm 0.55 \mathrm{~g} / 100 \mathrm{~g}$ (Table 2). No significant difference $(\mathrm{p}>0.05)$ between the stages of processing in the organic nuts (Table 1) indicate that there was no loss and no gain of palmitic acid during processing. In the nuts obtained from conventional cultivation, little variation

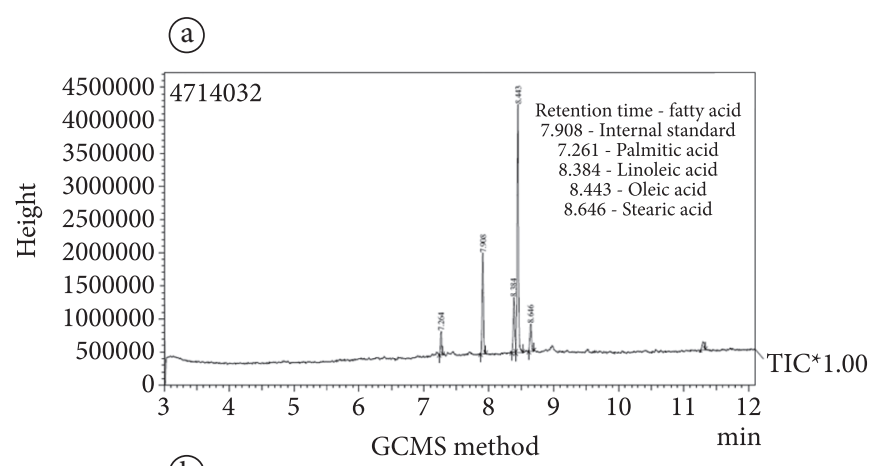

(b)

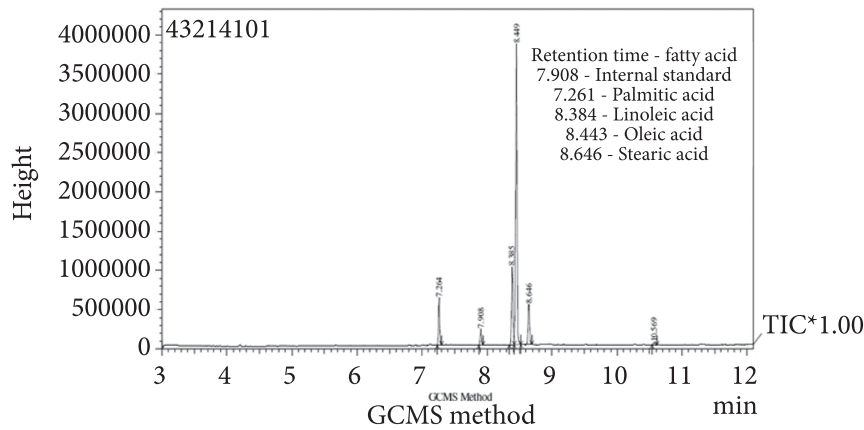

Figure 2. Chromatogram of the analysis of fatty acids prevalent in cashew nuts obtained from conventional (a) and organic cultivation (b) in different stages of processing.

Table 1. Tukey test of mean values of the palmitic and stearic fatty acids found in cashew nuts obtained from conventional and organic cultivation in different stages of processing.*

\begin{tabular}{|c|c|c|c|c|}
\hline \multirow[t]{2}{*}{ Collection stages } & \multicolumn{2}{|c|}{ Palmitic (g/100 g) } & \multicolumn{2}{|c|}{ Stearic $(\mathrm{g} / 100 \mathrm{~g})$} \\
\hline & Conventional & Organic & Conventional & Organic \\
\hline Before peeling & $7.04^{\mathrm{ab}}$ & $7.01^{\mathrm{a}}$ & $8.48^{\mathrm{a}}$ & $8.10^{\mathrm{ab}}$ \\
\hline During packaging & $7.13^{\mathrm{a}}$ & $7.12^{\mathrm{a}}$ & $8.27^{\mathrm{a}}$ & $8.92^{\mathrm{a}}$ \\
\hline
\end{tabular}

\footnotetext{
*Same letters within the same column are not statistically different by the Tukey test $(\mathrm{p} \leq 0.05)$.
} 
Table 2. Content of palmitic, linoleic, oleic, and stearic fatty acids in cashew nuts obtained from conventional and organic cultivation in different stages of processing.

\begin{tabular}{lcc}
\hline & Fatty acid & Average $(\mathrm{g} / 100 \mathrm{~g})(\mathrm{m} / \mathrm{m})$ \\
\hline Palmitic & $6.93 \pm 0.55$ \\
Linoleic & $16.99 \pm 0.61$ \\
Oleic & $67.62 \pm 1.00$ \\
Stearic & $8.42 \pm 0.55$
\end{tabular}

in the palmitic acid content between the stages of processing was observed.

Venkatachalam and Sathe (2006), working with different type of nuts, found palmitic acid values of $10.70 \mathrm{~g} / 100 \mathrm{~g}$ in cashew nuts, $15.11 \mathrm{~g} / 100 \mathrm{~g}$ in Brazil nuts, $5.78 \mathrm{~g} / 100 \mathrm{~g}$ in hazelnuts, and $6.20 \mathrm{~g} / 100 \mathrm{~g}$ in peanuts. Mexis and Kontominas (2009) found the content of $12.97 \mathrm{~g} / 100 \mathrm{~g}$ of palmitic acid in cashew nuts. The results reported by these authors with regard to cashew nuts are higher than those observed in this study.

There was no significant interaction $(\mathrm{p}>0.05)$ between the two forms of cultivation studied in terms of linoleic fatty acid content. For this fatty acid, significant interaction $(\mathrm{p}<0.05)$ between the stages of the processing was observed. Since there was no significant difference ( $p>0.05$ ) between the two forms of cultivation studied, the Turkey test was performed combining the two forms of cultivation focusing on the differences between the stages of collection (Table 3 ). The highest content of this fatty acid was found in nuts collected after shelling $(17.74 \mathrm{~g} / 100 \mathrm{~g})$, which were very different $(\mathrm{p}<0.05)$ from the nuts collected at the other stages which suggests that there is loss of linoleic acid during the cashew nut processing.

This reduction in linoleic acid during processing may result from the drying step, which was performed after shelling in which temperatures as high as $60-70{ }^{\circ} \mathrm{C}$ were used for several hours until the nut reached a final moisture content of 3 to 4\%. According to Sanibal and Mancini-Filho (2004), high temperatures can change the profile of unsaturated fatty acids (with the exception of oleic acid), and this can cause an increase in the content of saturated fatty acids due to the proportional decrease of polyunsaturated fatty acids.

The main value observed in this study for the linoleic acid $(16.99 \pm 0.61 \mathrm{~g} / 100 \mathrm{~g})$ (Table 2) is similar to that reported by Mexis and Kontaminas (2009) (17.04 g/100 g) and higher to that reported by FAO (FOOD..., 2010) (7.67 g/100 g) in cashew nuts.

The main value of oleic acid observed in the present study was $67.62 \pm 1.00 \mathrm{~g} / 100 \mathrm{~g}$ (Table 2), which is smaller than that reported by FAO (FOOD..., 2010) (73.3 g/100 g) and higher than that observed by Venkatachalam and Sathe (2006) (61.15 g/100 g) and by Mexis and Kontominas (2009) $(49.08 \mathrm{~g} / 100 \mathrm{~g})$. There was no significant difference $(\mathrm{p}>0.05)$ between the stages of processing and the cultivation forms, showing that there were no losses of oleic acid during the processing and that the form of cultivation used did not change the oleic acid content. Since no difference was observed, there was no need to perform the Tukey test for this fatty acid.
Table 3. Tukey test of mean values of the linoleic fatty acid found in cashew nuts obtained from conventional and organic cultivation in different stages of processing.*

\begin{tabular}{lc}
\hline \multirow{2}{*}{ Collection stages } & Mean Square \\
\cline { 2 - 2 } & Linoleic $(\mathrm{g} / 100 \mathrm{~g})$ \\
\hline After the shelling & $17.74^{\mathrm{a}}$ \\
Before peeling & $16.87^{\mathrm{b}}$ \\
After peeling & $16.76^{\mathrm{b}}$ \\
During packaging & $16.58^{\mathrm{b}}$ \\
\hline
\end{tabular}

${ }^{\star}$ Same letters are not statistically different by the Tukey test $(\mathrm{p} \leq 0.05)$.

Venkatachalam and Sathe (2006) studied fatty acids in nuts and found values of 16.88 and $61.15 \mathrm{~g} / 100 \mathrm{~g}$ (cashew nut), 45.43 and $28.75 \mathrm{~g} / 100 \mathrm{~g}$ (Brazil nut), 7.55 and $82.95 \mathrm{~g} / 100 \mathrm{~g}$ (hazelnut), and 3.87 and $81.23 \mathrm{~g} / 100 \mathrm{~g}$ (peanut) of linoleic and oleic acids, respectively. These results indicate that cashew nut and the other nuts have high content of the essential linoleic fatty acid and the oleic fatty acid.

According to FAO (FOOD..., 2010), the oleic content of peanuts is higher than that of the cashew nuts, while the content of linoleic acid is at least three times lower, which is consistent with the results found in the present study.

With regards to the stearic fatty acid, the main value found was $8.42 \pm 0.55 \mathrm{~g} / 100 \mathrm{~g}$, which is smaller than that reported by FAO (FOOD..., 2010) (11.24 g/100 g) and by Mexis and Kontominas (2009) (17.80 g/100 g) in cashew nuts. There was no significant difference $(p>0.05)$ between the stages of processing of conventional nuts (Table 2).

There was no significant difference $(p>0.05)$ between the two methods of cultivation studied in terms of the palmitic, linoleic, oleic and stearic fatty acid contents, which indicates that the cultivation method does not influence the fatty acid content in cashew nuts.

Several studies in the literature have demonstrated differences in the composition of foods produced by the organic cultivation system compared to those produced by the conventional system (PINHO et al., 2008; VALLVERDÚQUERALT et al., 2012; KELLY; BATEMAN, 2010). There are, however, no reports specifically detailing the differences in the fatty acid profile of cashew nuts produced by the conventional and by the organic systems.

Cashew nut has a high content of monounsaturated and polyunsaturated fatty acids. In the present study, $67.62 \%$ and $16.99 \%$ of MUFA and PUFA were found, respectively. A different value of MUFA in cashew nuts was reported by Mexis and Kontominas (2009) (50\%). The difference between the fatty acid content found in the present study compared with that found by other authors may be due to the methodologies used for extraction and quantification, species, growing conditions, and climate (NASSU; LIMA; PAIVA, 2004), and according to Mexis and Kontominas (2009), it may be due to differences in the cultivars and maturity during the harvest.

According to FAO (FOOD..., 2010), 66\% of the essential fatty acids required is supplied by the intake of cereals, vegetables, and milk. To provide the remaining $33 \%$, the intake 
of different vegetable oils from various sources of nuts and seeds is necessary.

\section{Conclusion}

The most important fatty acids found in cashew nuts were the palmitic, linoleic, oleic and stearic acids. The average levels of these fatty acids were: $6.93 \pm 0.55 ; 16.99 \pm 0.61 ; 67.62 \pm 1.00$, and $8.42 \pm 0.55$, respectively.

Cashew nuts showed high levels of the essential linoleic fatty acid, which was the only fatty acid whose levels decreased during processing.

Little variation occurred in the content of the following fatty acids: palmitic, linoleic, oleic and stearic in the two methods of cultivation confirming that the method of cultivation does not change the fatty acid content.

The lack of any significant difference in the levels of fatty acids in cashew nuts produced by the two different methods of cultivation, conventional and organic, does not influence the fact that there are benefits to consuming organic cashew nut since although this nut has a fatty acid profile similar to that observed in the conventional cashew nut, it still offer the advantage of being free of fertilizers and pesticides.

\section{References}

AGRORGÂNICA. Agricultura Orgânica. Disponível em: <http:// www.agrorganica.com.br/agriculturaorg.html $>$. Acesso em: 09 jan. 2013.

AMICO, V. et al. Antiproliferative Terpenoids from Almond Hulls (Prunus dulcis): Identification and Structure-Activity Relationships. Journal of Agricultural and Food Chemistry, v. 54, n. 3, p. 810814, 2006. http://dx.doi.org/10.1021/jf052812q

BLIGH, E. G.; DYER, W. J. A rapid method of total lipid extraction and purification. Canadian Journal of Biochemistry and Physiology, v. 37, n. 8, p. 911-917, 1959. http://dx.doi.org/10.1139/o59-099

BLOMHOFFI, R. et al. Health benefits of nuts: potential role of antioxidants. British Journal of Nutrition, v. 96, n. 2, p. 52-60, 2006. http://dx.doi.org/10.1017/BJN20061864

CHEN, C. Y.; LAPSLEY, K.; BLUMBERG, J. B. A nutrition and health perspective on almonds. Journal of the Science of Food and Agriculture, v. 86, n. 14, p. 2245-2250, 2006. http://dx.doi. org/10.1002/jsfa.2659

CHITARrA, M. I. F.; CHITARRA, A. B. Pós-Colheita de Frutas e Hortaliças: fisiologia e manuseio. 2nd ed. Lavras: Universidade Federal de Lavras, 2005. 783 p.

CRECENTE-CAMPO, J. et al. Color, anthocyanin pigment, ascorbic acid and total phenolic compound determination in organic versus conventional strawberries (Fragaria x ananassa Duch, cv Selva). Journal of Food Composition and Analysis, v. 28, n. 1, p. $23-$ 30, 2012. http://dx.doi.org/10.1016/j.jfca.2012.07.004

FAGUNDES, L. A. Ômega-3 de Ômega-6: o equilíbrio dos ácidos gordurosos essenciais na prevenção de doenças. Porto Alegre: Editora Age LTDA, 2002. 1894 p.

FOOD AND AGRICULTURE ORGANIZATION OF THE UNITED NATIONS - FAO. Integrated production practices of cashew in Asia. Disponível em: <http://www.fao.org/docrep/005/ac451e/ ac451e0b.htm>. Acesso em: 06 abr. 2010.
GLOVER, J. D.; REGANOLD, J. P.; ANDREWS, P. K. Systematic method for rating soil quality of convencional, organic, and integrated apple orchards in Washington State. Agriculture, Ecosystems \& Environment, v. 80, p. 29-45, 2000. http://dx.doi. org/10.1016/S0167-8809(00)00131-6

HEINIG, R. E. The patient with diabetes: preventing cardiovascular complications. Clinical Cardiology, v. 29, p. 13-20, 2006. Supplement 10.

INSTITUTO ADOLFO LUTZ - IAL. Métodos físico-químicos para análise de alimentos. 4th ed. São Paulo: Instituto Adolfo Lutz, 2008. 1020 p.

INSTITUTO BIODINÂMICO - IBD. Projetos certificados IBD. Botucatu, 2010. Disponível em: <http://www.ibd.com.br/News_ Detalhe.aspx?idnews=194>. Acesso em: 09 jan. 2013.

KELLY, S. D.; BATEMAN, A. S. Comparison of mineral concentrations in commercially grown organic and conventional crops - Tomatoes (Lycopersicon esculentum) and lettuces (Lactuca sativa). Food Chemistry, v. 119, n. 2, p. 738-745, 2010. http://dx.doi.org/10.1016/j. foodchem.2009.07.022

LIMA, J. R.; DUARTE, E. A. Pastas de castanha de caju com incorporação de sabores. Pesquisa Agropecuária Brasileira, v. 41, n. 8, p. 1333-1335, 2006. http://dx.doi.org/10.1590/S0100204X2006000800019

LI, S. C. et al. Almond consumption improved glycemic control and lipid profiles in patients with type 2 diabestes mellitus. Metabolism Clinical and Experiment, v. 60, n. 4, p. 474-479, 2011. http://dx.doi. org/10.1016/j.metabol.2010.04.009

LOMBARDO, S.; PANDINO, G.; MAUROMICALE, G. Nutritional and sensory characteristics of "early" potato cultivars under organic and conventional cultivation systems. Food Chemistry, v. 133, n. 4, p. 1249-1254, 2012. http://dx.doi.org/10.1016/j.foodchem.2011.10.005

MAGUIRE, L. S. et al. Fatty acid profile, tocopherol, squalene and phytosterol content of walnuts, almonds, peanuts, hazelnuts and the macadamia nut. International Journal of Food Sciences and Nutrition, v. 55, n. 3, p. 171-178, 2004. http://dx.doi.org/10.1080/ 09637480410001725175

MEXIS, S. F.; KONTOMINAS, M. G. Effect of $\gamma$-irradiation on the physicochemical and sensory properties of cashew nuts (Anacardium occidentale L.). Food Science and Technology, v. 42, n. 9, p. 1501-1507, 2009.

MEZZOMO, N. et al. Supercritical fluid extraction of peach (Prunus persica) almond oil: Process yield and extract composition. Bioresource Technology, v. 101, n. 14, p. 5622-5632, 2010. http:// dx.doi.org/10.1016/j.biortech.2010.02.020

NASSU, R. T.; LIMA, J. R.; PAIVA, F. F. A. Boas práticas no processamento de castanha de caju. Fortaleza: Embrapa Agroindústria Tropical, 2004. 36 p.

PAIVA, F. F. A.; GARRUTI, D. S.; SILVA NETO, R. M. Aproveitamento industrial do caju. Fortaleza: Embrapa Agroindústria Tropical, 2000. $88 \mathrm{p}$.

PINHO, L. et al. Qualidade de milho verde cultivado em sistemas de produção orgânico e convencional. Revista Brasileira de Milho e Sorgo, v. 7, n. 3, p. 279-290, 2008.

RYAN, E. et al. Fatty acid profile, tocopherol, squalene and phytosterol content of Brazil, pecan, pine, pistachio and cashew nuts. International Journal of Food Science and Nutrition, v. 57, n. 3-4, p. 219-228, 2006. http://dx.doi.org/10.1080/09637480600768077

SANIBAL, E. A. A.; MANCINI FILHO, J. Perfil de ácidos graxos trans de óleo e gordura hidrogenada de soja no processo de fritura. 
Ciência e Tecnologia de Alimentos, v. 24, n. 1, p. 27-31, 2004. http:// dx.doi.org/10.1590/S0101-20612004000100006

SILVA, R. F.; ASCHERI, J. L. R.; SOUZA, J. M. L. Influência do processo de beneficiamento na qualidade de amêndoas de castanha-do-Brasil. Revista Ciência e Agrotecnologia, v. 34, n. 2, p. 445-450, 2010. http://dx.doi.org/10.1590/S1413-70542010000200025

SOARES, D. J. et al. Characterization and antioxidant activity of cashew nut bran in different stages of processing. Boletim do Centro de Pesquisa de Processamento de Alimentos, v. 30, n. 1, p. 147-153, 2012a.

SOARES, D. J. et al. Study of the stability of cashew nuts obtained from conventional and organic cultivation. Semina: Ciências Agrárias, v. 33, n. 5, p. 1855-1868, 2012b. http://dx.doi.org/10.5433/16790359.2012v33n5p 1855

STATISTICAL ANALISYS SYSTEM INSTITUTE - SAS. Sas Institute Inc. versão 8.1. Cary, 2006.

SUÁREZ-MAHECHA, H. et al. Importância de ácidos graxos poliinsaturados presentes em peixes de cultivo e de ambiente natural para a nutrição humana. Boletim do Instituto de Pesca, v. 28 , p. $101-110,2002$.
TINOCO, S. M. B. et al. Importância dos ácidos graxos essenciais e os efeitos dos ácidos graxos trans do leite materno para o desenvolvimento fetal e neonatal. Caderno de Saúde Pública, v. 23 , n. 3, p. 525-534, 2007. http://dx.doi.org/10.1590/S0102311X2007000300011

TUDELA, J. A.; ESPÍN, J. C.; GIL, M. I. Vitamin C retention in freshcut potatoes. Postharvest Biology and Technology, v. 26, n. 1, p. 75-84, 2002. http://dx.doi.org/10.1016/S0925-5214(02)00002-9

VALLVERDÚ-QUERALT, A. et al. Is there any difference between the phenolic content of organic and conventional tomato juices? Food Chemistry, v. 130, n. 1, p. 222-227, 2012. http://dx.doi. org/10.1016/j.foodchem.2011.07.017

VENKATACHALAM, M.; SATHE, S. K. Chemical composition of selected edible nut seeds. Journal of Agricultural and Food Chemistry, v. 54 , n. 13 , p. $4705-4714,2006$. http://dx.doi. org/10.1021/jf0606959

ZHANG, D.; HAMAUZU, Y. Phenolics, ascorbic acid, carotenoids and antioxidant activity of broccoli and their changes during conventional and microwave cooking. Food Chemistry, v. 88, n. 4, p. 503-509, 2004. http://dx.doi.org/10.1016/j.foodchem.2004.01.065 